\title{
Legal Relationship in Health Services
}

\author{
Iman Firmansyah \\ \{hi_firmansyah@yahoo.com \} \\ Postgraduate Jayabaya University, Jakarta, Indonesia
}

\begin{abstract}
The doctor-patient relationship originally occurs as a therapeutic relationship, because of the existence of a medical transaction, then arise a legal relationship between both of two parties. Indeed, the doctor-patient relationship in this article is just within the context of legal relation. Using a normative juridical writing method, the result of this study aims the concept of therapeutic agreements that give rise to legal relation in health services. The doctor must always be responsible for carrying out his profession, and also understand the legal provisions that apply in the implementation of their profession, including the rights and obligations of doctors and patients.
\end{abstract}

Keywords: therapeutic relationship, medical transaction, legal relationship

\section{Introduction}

Health Law can be formulated as all legal regulations that are directly related to the maintenance of health and its application to the civil law, administrative law, and criminal law. ${ }^{1}$ The influence of globalization changes view of life causes socio-culture alteration, and ways of thinking. In the health sector, the development of science and technology may increase in the critical thought on society. The doctor-patient relationship that had been paternalistic and based on trust (fiduciary relationship) was shifted to a partnership pattern (patient-center care).

In Indonesia, health law develops along with the dynamics of life, regulates more legal relationships in health services, and more specifically health law regulates health services among doctor, hospital, health center, and other health care workers with patients. ${ }^{2}$ Because of it's a basic right that must be fulfilled, a health law is united in one regulation, namely the ratification of Act Number 23 of 1992 concerning Health, that was amended by Act Number 36 of 2009 concerning Health.

Health law in Indonesia is expected to be more flexible and able to follow the development of science and technology in the field of medicine. One of the objectives of the law, regulation, declaration or code of health ethics is to protect the interest of patients while developing the quality of the profession of doctors or health care workers. ${ }^{3}$ Harmony between the interest of patients and the interest of health care workers is one of the supports for the success of the

${ }^{1}$ Guwandi, J.: Hukum Medik (Medical Law). Balai Penerbit FKUI, Jakarta (2010).

${ }^{2}$ Suherman, A.M.: Aspek Hukum Dalam Ekonomi Global. Ghalia Indonesia, Jakarta (2002).

${ }^{3}$ Guwandi, J.: Hukum Medik (Medical Law). Balai Penerbit FKUI, Jakarta (2010). 
development of the health system. Therefore, health law which governing health services to the patient is closely related to the problems that will arise within the relationship between doctor and patient, and/or negligence and mistake are made by doctor, which result in law, whether it's civil or criminal law.

Indeed, the doctor-patient relationship in this article is just within the context of legal relation. Although the doctor-patient relationship originally occurs as a medical/therapeutic relationship, because of the existence of a medical transaction between both of them, then arises a legal relationship between both of two parties. Both of doctor and patient are expected to know this legal relationship, so that all parties may know their rights and obligations when the legal problems occur in the future.

\section{Method}

This article uses normative juridical writing method, by using statute approach and conceptual approach, by examining the laws and regulations related to the health law and conceptual understanding in doctrines and opinions of experts in the legal relationship in health services.

\section{Result and Discussion}

\subsection{Therapeutic transactions}

Health services in the term of health care means an effort to maintain and improve the less function organ, helping the weak or dangerous human condition, and who are always moving towards better, stronger, safer and more comfortable, towards perfection. These efforts are not only material, but also the immaterial activities which directed to personal service. The purpose of these health services are motivation of dedicated and prudent health care. ${ }^{4}$ Other aspects of health services are technical skills of health care providing.

Health services must appropriate and sustainable. Appropriate could have a subjective and relative meaning. Subjective describes a manner, for example, health services experience from someone can provide good, in accordance with his or her expectation. More than that, subjectivity must be seen and linked to the time, place, and circumstances. For example, special health services with sophisticated facilities and infrastructure in the United States are not necessarily considered appropriate by Indonesian people.

According to Jusuf Hanafiah and Amri Amir, in a medical or health profession work place, when the patients see the doctor to solve his or her health problems including preventive, curative, or rehabilitative services, then there have been a transaction and agreement between the two parties in the health sector ${ }^{5}$. According to the provisions of the law, such relations apply as law. It means that each party has rights and obligations that must be obeyed. In case, one party does not fulfill its obligations, the injured party can sue the other party.

Transaction means engagement and agreement that is correlation on both sides between two parties who agreed with one thing. Therapeutic means within medicinal treatment. It is a little bit different with therapy, which means treatment. Actually, the doctor-patient agreement is not just

${ }^{4}$ Tengker, F.: Hak Pasien. Penerbit CV Mandar Maju, Bandung (2007).

${ }^{5}$ Hanafiah, J. \& Amir, A.: Etika Kedokteran dan Hukum Kesehatan. Penerbit Buku Kedokteran EGC, Jakarta (2012). 
therapy, but more than that, including the diagnostic, promotion, preventive, curative, and rehabilitative services, so this agreement is called therapeutic transaction.

In the field of medication, doctors and the public must realize that it is not possible for doctors to guarantee that treatment efforts will always succeed as desired by the patient or patient's family. What a doctor can give is maximum effort. Jusuf Hanafiah and Amri Amir argued that the doctorpatient relationship in a civil law agreement was included in the engagement category based on maximum effort (inspaningsverbintenis). This is different from the engagement based on work results (resultverbintenis) ${ }^{6}$

The doctor-patient relationship that has a legal basis can be seen from Article 1313 of the Civil Code, An agreement is an act by one or more people who commit themselves to one or more people. In medication sector, there is a clear relationship or agreement between the patient side and the doctor side. The patient or patient's family in one side needs the intelligence and skills of the doctor to deal with himself or herself and his or her family's health problems, while on the other hand the doctors have that intelligence and skills that can provide the patient's recovery. ${ }^{7}$ Therefore, as a consequence of this agreement, an engagement between the two parties will occur. Both of them agree and promise to do something medication or health services. Finally, this agreement between the doctor and the patient will becomes an engagement between the two parties.

The regulation explains that engagement means a legal relationship between two or more people, which one party entitled to demand something from the other party, while the other party is obliged to fulfill these demands. From this provision, it can be seen that in health services, there is a relationship between patient or patient's family who ask for help the doctors, and by their expertise are able to meet the assistance requested by patient or patient's family. In this case, it is mention that the patient or patient's family demands an achievement from the doctor.

The meaning of achievements according to the law is:

1. Delivering the goods;

2. Do something; or

3. Did not commit an act. In the context of doctor-patient relationship, the main achievement is doing an act, both in the framework of promotional, preventive, curative, and rehabilitation.

In the certain cases, this achievement can also mean not doing anything. For example, when a doctor faced a patient suffering from abscess appendicitis, then the doctor decides to do not perform appendectomy at this stage, it is an achievement.

The legal requirement for a doctor-patient agreement is to fulfill the following conditions according to Article 1320 of the Civil Code:

1. Agreement to commit.

In term of the doctor-patient relationship, it is easily understood, because of when one party disagrees, there will be no therapeutic transaction. The patient agrees with the doctor he chooses, and the doctor is able to deal with the health problems of patient who come to see him.

2. Ability to make an agreement.

${ }^{6}$ Hanafiah, J. \& Amir, A.: Etika Kedokteran dan Hukum Kesehatan. Penerbit Buku Kedokteran EGC, Jakarta (2012).

${ }^{7}$ Ide, A.: Etika dan Hukum dalam Pelayanan Kesehatan. Gracia Publicer, Yogyakarta (2012). 
This skill must exist on both sides, those who provide and require services. On the part of the patient according to this provision requires competent people to make a statement, namely a sane adult. In different condition, there must be someone who escorts as a patient companion. Likewise the doctors and other health care workers side. Physicians must have skills required by patients, as a general practitioner or specialist according to their specialization. That must have proof, such as a certificate of competence recognized by government or the expert association.

3. A certain thing.

Certain thing in a doctor-patient agreement is a disease or condition that needs to be covered by a doctor. Something here does not mean just one thing; it can be more than one. The outpatient may submit complaints to be overcome from head to toe. However, the problem is the specific action such as surgery and other invasive measures. In Caesarean section, delivering baby through surgery accompanied with removing the patient's appendix with no pathological condition actually violates the agreement. In the same condition, the doctor found the patient's appendix is inflamed and needs to be removed immediately, it isn't appropriate if the Caesarean section is closed first, then the appendix surgery is done. The doctor can remove the pathological appendix, but after the patient has regained consciousness, it must be stated that the action is forced to be carried out. This is regulated in Minister of Health Regulation Number 290 of 2008 concerning Approval of Medical Measures (article 7, paragraph 2 and 3).

4. Halal causes.

The point is that something bound doesn't break the law. In this case, everything against the law is illegal abortion, cosmetic surgery to avoid the police arrest, or removing fingerprints, etc.

Therapeutic approval does not always run smoothly. Sometimes the one party does not want to continue the transaction. Generally, those who do not want to continue the transaction is the patient or the patient's family. For the outpatient, it is easy to do that. No longer visiting for reexamination is an act of breaking ties. However, if this happens on the patient being hospitalized, the doctor must be careful. Letting patient discharge from the hospital, even though all treatment costs have been paid is a rash action. Patients or their families are asked to sign a statement going home at their own request in the medical record document. Although it is sufficient, it would be better if the cancellation of the original agreement was done correctly, through official cancellation as well. In a special sheet stated that the doctor has explained the patient's condition and the actions needed, but the patient and family asked to go home with all risks outside the doctor's responsibility. Cancellation sheets like this will have stronger legal force. ${ }^{8,9}$

On the other hand, the doctor can also decide to break the agreement with the patient, for example, in case of the doctor facing an uncooperative patient and unsure of his treatment efforts, the doctor can ask the patient to see another doctor. In this case, the doctor should include a final resume for the doctor who will continue treatment and care.

In the cancellation of therapeutic approval must pay attention to the provisions of Article 1338 of the Civil Code, which states that all agreements made legally apply as a law to the party

${ }^{8}$ Isfandyarie A.: Tanggung Jawab Hukum dan Sanksi bagi Dokter Buku 1. Prestasi Pustaka Publisher, Jakarta (2006).

${ }^{9}$ Kusumastuti, E.: Transaksi Terepeutik dalam Upaya Pelayanan Medis di Rumah Sakit. PT Citra Aditya Bakti, Bandung (2009). 
who made it, and cannot be withdrawn other than by the agreement of both parties or for reasons stated sufficiently by law. Cancellation of this agreement does not always have to be written. In circumstances deemed sufficient by law, the agreement can be declared null and void. However, in canceling therapeutic consent, the doctor needs to be careful of risks that can arise in the future.

\subsection{The principles in medical services as an implementation of therapeutic transaction}

According to Komalawati, the underlying legal principle to implements the therapeutic transactions are: ${ }^{10}$

1. The principle of legality

Health care workers in charge of organizing health activities must have expertise in accordance with the field of expertise and/or an authority of the health worker concerned. It means that the medical services can only performed after fulfill the regulated requirement and permit in legislation, namely Act Number 29 of 2004 concerning Medical Practices.

2. The principle of balance

Depends on this principle, the health services must be carried out in a balanced manner between the individual and society interests, physical and mental health, material and spiritual properties. In medical services, it can also be interpreted as a balance between goal and facility, facility and result, risk and benefit, arising from undertaken medical efforts.

3. On time principles

In health services, this is a quite important principle, because due to negligence to provide right help when needed can harm the patient. This principle must be considered by doctors, because the law cannot provide any reason in terms of the safety of life of threatened patient due to the doctor's delay in handling him.

4. The principle of good faith

This principle is based on the ethical principle of doing well (beneficence) that must be applied in the implementation of doctor's obligation to the patient. As a professional, the application of this principle will be reflected in respect for the rights of patient and the implementation of medical practices that always adhere to professional standard. The obligation to do well benefit is not certainly without limits, because doing well benefit may not harm them.

5. The principle of honesty

Honesty is one of the important principles to be able to foster patient confident in doctors. Based on this principle of honesty, doctors are required to provide assistance in accordance with what patient needed, which is in accordance with professional standard. The available various facilities at a medical service institution are only carried out in accordance with the patient needed. This principle is the basis for the delivery of correct information, both in patient and doctor communication. Honesty in conveying information will be very helpful in the patient's recovery. The truth of this information is closely related to the right of every human being to know the truth.

6. The Principle of carefulness

\footnotetext{
${ }^{10}$ Komalawati, D.V.: Peranan Informed Consent dalam Transaksi Terapeutik: Persetujuan dalam Hubungan Dokter dan Pasien, Suatu Tinjauan Yuridis. Penerbit Citra Aditya Bakti, Bandung (2002).
} 
As a professional medical worker, the doctor's performance must be based on accuracy in carrying out their function and responsibilities, because of carelessness in a medical service can cause life threatened; then the doctor being exposed to a criminal prosecution. While carrying out the obligation of doctor, this principle is applied by completing professional standard and respecting the rights of patient, especially the rights of information and the right to give consent (informed consent); that is closely related to therapeutic transactions. ${ }^{11}$ The doctor's negligence in carrying out his duties without adhering to professional standard and without making informed consent letter can be considered as an act that harms the patient, until the patient is entitled to compensation. Ethically, health services have the principle of no harm (non-maleficent), which is technically as the form of an obligation not to harm others. This non-harm principle is the primum non-nocere principles (importantly, not to harm).

7. The principle of openness

The effective and succeed medical services can only be achieved if there are openness and good cooperation between doctor and patient based on mutual trust. ${ }^{12}$ This attitude is grown when openness communication is established between doctor and patient; the patient gets an explanation from the doctor in transparent communication.

Slightly different from Komalawati and Fuady mentions opinion about some of the principles of modern ethics from medical practice, as follows: ${ }^{13,14}$

1. The principle of autonomy

This principle requires the patient who has capacity to act as capable legal subject is given the opportunity to make rational choices; as a form of respect for their human rights to determine their own destiny (self-determination). Although the patient made a mistaken, the doctors must respect him constantly and try to explain the truth according to their knowledge and professional skills until the patient really understands the consequences of his or her choice if it's not in accordance with the doctor's recommendations.

2. The principle of generosity

This is known as beneficence, namely a suggestion for the doctor to always giving help to their patients generously. Doing virtue, kindness and generosity are generally accepted recommendation for doctors and those are applied in professional service.

3. Do not hurt principle

Along treating the patient, doctor should try not to hurt the patient (non-maleficent). Sometimes, this is difficult to do because during treating the patient, the treatment itself causes pain to the patient. In such case, the doctor must provide an explanation about the pain that might arise during following a medical treatment.

4. The principle of justice

Justice in this case is in providing medical services in the sense that the doctor must provide treatment fairly regardless of socioeconomic status.

5. The principle of loyalty

\footnotetext{
${ }^{11}$ Guwandi, J.: Informed Consent. Balai Penerbit FKUI, Jakarta (2004).

${ }^{12}$ Guwandi, J.: Dokter, Pasien, dan Hukum. Balai Penerbit FKUI, Jakarta (1996).

${ }^{13}$ Komalawati, D.V.: Peranan Informed Consent dalam Transaksi Terapeutik: Persetujuan dalam Hubungan Dokter dan Pasien, Suatu Tinjauan Yuridis. Penerbit Citra Aditya Bakti, Bandung (2002).

${ }^{14}$ Munir, F.: Sumpah Hipocrates: Aspek Hukum Malpraktek Dokter. PT Citra Aditya Bakti, Bandung (2005).
} 
This principle is a translation of fidelity which means the doctor must be trustworthy and loyal to the mandate given by the patient with a full sense of responsibility to use all their knowledge and skills for the safety of his patients' lives.

6. The principle of honesty

The principle of honesty (veracity) requires honesty from both parties, both doctors and patients. The doctor must honestly state the results of observations and examinations conducted on patients, and patients must also honestly reveal the history of the disease.

\subsection{The rights and obligations of doctors and patients}

According to Article 1 of Act Number 29 of 2004 concerning Medical Practice, a patient is any person who consults his health problems to obtain the necessary health services either directly or indirectly to doctor or dentist.

The legal aspects of health care workers originate from Government Regulation Number 32 of 1996 concerning Health Care Workers and are detailed in Act Number 36 of 2009 concerning Health. Within this law it is regulated that health care workers must have minimum qualifications.

In addition to qualifications, health care workers have the authority to organize these health services in accordance with the following provisions: ${ }^{15}$

1. Done in accordance with the field of expertise possessed

2. During providing the health services, every health care worker must have government license

3. While providing these health services, prohibited to prioritize materially valued interests

The government regulates the planning, procurement, utilization, guidance, and supervision of the quality of health care workers in the framework of organizing health services. Provisions regarding the planning, procurement, utilization, guidance and quality control of health care workers are regulated in a Government Regulation. Likewise, the provisions regarding health care workers will be regulated by law. In addition, the government also organizes education, and improves the quality of health care workers through education and/or training.

The authorized health care workers must meet the following provisions:

1. Code of ethic

2. Professional standard

3. User rights of health services

4. Service standard

5. Standard operational procedure

Provisions on codes of ethics and professional standards are regulated by the professional organizations concerned. Whereas provisions regarding the user rights of health services, service standard, and standard operating procedures are regulated by a Minister of Health Regulation. The government regulates the placement of health care workers to average out distribution of health services. While a province or district governments can organize and utilize health care workers in accordance with the needs of their respective regions. Provision of utilization of health care workers must consider:

${ }^{15}$ Notoadmodjo, S.: Etika dan Hukum Kesehatan. Penerbit Rineka Cipta, Jakarta (2010). 
1. Types of health services needed by the community

2. Number of health services facilities

3. The number of health care workers in accordance with the workload of existing health services

It should be remembered that the placement of health care workers is carried out regarding the rights of each health care worker and the community to obtain equitable health services.

Health care workers have rights, obligations and authorities, including:

1. Get compensation and legal protection in carrying out their duties in accordance with their profession

2. Obliged to develop and enhance their knowledge and skills. Provisions regarding the rights and obligations of health care workers are regulated in a Government Regulation

3. For the legal interest, health care workers are required to conduct a health services on demand of law enforcement with costs borne by the state

4. The government rules of placement is based on each scientific competence and authority

Doctor's obligation to patient are contained in the Indonesian Medical Ethics Code (KODEKI) in articles 10 to 13, and are clarified in articles 50 and 51 of Act Number 29 of 2004 concerning Medical Practice, while the right and obligation of patient in articles 52 and 53. Violations of the obligation may result in the doctor being exposed to criminal threats. Article 50 of the Medical Practice Law states that doctors and dentists in medical practices have the right:

1. Obtain legal protection as long as carrying out duties in accordance with professional standards and standard operating procedures

2. Providing medical services according to the professional standards and operational procedure standards

3. Obtain complete and honest information from patients or their families

4. Receive service fees

Associated with a therapeutic contract between doctor and patient, the doctor rights regarding Komalawati are added as follows: ${ }^{16}$

1. The right to patient information regarding complaints

2. Right to service and honorarium fees

3. The right to terminate the relationship with the patient, if the patient does not comply with the given advice

4. The right to patient good faith in carrying out therapeutic transactions

5. Right to privacy

According to the doctor rights listed in Article 50 of the Medical Practice Act, the patient obligations arose outlined in article 53, namely:

1. Provide complete and honest information about his health problems

2. Obey the doctor advice and instructions

3. Comply with applicable provisions in health service facilities

4. Providing service fees for service obtained

\footnotetext{
${ }^{16}$ Komalawati, D.V.: Peranan Informed Consent dalam Transaksi Terapeutik: Persetujuan dalam Hubungan Dokter dan Pasien, Suatu Tinjauan Yuridis. Penerbit Citra Aditya Bakti, Bandung (2002).
} 
Related to the patient obligations to provide complete and honest information, there is the doctrine of contributory negligence, which can be translated as problem patients. Here it is seen that not only health care workers can be considered negligent, but patients can also be guilty of causing the disease to worsen. ${ }^{17}$

The contributory negligence category, are includes:

1. Patients do not obey their doctor's instructions (including not buying medicines that are in accordance with the doctor's prescription),

2. Patient refuses the proposed treatment method (the patient refuses surgery, then dies, then the doctor cannot be blamed),

3. Patients are not honest in providing information or provide inaccurate information or misleading

In addition to being listed in the Medical Practice Law, KODEKI also mentions the rights of patients, as follows:

1. The right to life, the right to his owns body and the right to die naturally

2. The right to obtain humanity medical services in accordance with the standard of the medical profession. In case the doctor does not provide services as professional standards, and then causes in disability or death, then the doctor has violated the patient's right to obtain such humanity services, so that the patient has the right to sue the doctor.

3. The right to obtain an explanation of the diagnosis and therapy from the doctor. The point of this information right is the patient's right to obtain information as clearly as possible about matters relating to his illness. In the event of a doctor-patient relationship, the patient rights to this information automatically becomes the doctor's obligation to be carried out whether requested or not by the patient. ${ }^{18}$

4. The right to get an approved diagnostic and therapeutic procedure, and even withdraw from a therapeutic contract. Accepting and rejecting something offered is a part of human rights, as is the case with medical measure. In the event that a patient refuses an offered medical measure, the doctor must not impose his will as long as he knows that it can have a negative impact on patient healing. ${ }^{19}$ The coercion of the doctor for the patient to take certain medical measure on the patient's body, while the doctor has good intentions to save the patient's life, will result in the doctor being sued at the request of malpractice.

5. The right to obtain an explanation of medical research to be followed and to refuse or accept its participation in that's medical research.

6. The right to be referred to a specialist if necessary, and returned to the doctor who referred him after the completion of consultation or treatment to obtain treatment or follow up.

7. The right to confidentiality or personal medical record. The patient's right to the confidentiality of his illness is protected by Article 322 of the Criminal Code (KUHP) and clarified in the Medical Practice Act.

8. The right to obtain an explanation of hospital regulations.

9. The right to deal with family, counselors or clergy, etc. as needed during treatment in hospital.

10. The right to obtain an explanation all details of medical costs for inpatient or outpatient care.

${ }^{17}$ Guwandi, J.: Hukum Medik (Medical Law). Balai Penerbit FKUI, Jakarta (2010).

${ }^{18}$ Supriadi, W.C.: Hukum Kedokteran. Penerbit CV Mandar Maju, Bandung (2001).

19 Machmud, S.: Penegakan Hukum dan Perlindungan Hukum bagi Dokter yang Diduga Melakukan Malpraktik. Penerbit Mandar Maju, Bandung (2008). 
Based on article 51 and 52 of The Medical Practice Law, doctors have obligations to:

1. Providing medical services in accordance with professional standard and standard operational procedure, and medical needs of patients

2. Referring patients to other doctors who have better skills or abilities, if unable to conduct an examination or treatment

3. Keep everything he knows about the patient, even if the patient was died

4. Carry out emergency relief on the basis of humanity, unless the doctor believes that someone else is on duty and is able to do so

5. Adding knowledge and following medical science development

The most frequent legal problems arising from the relationship between doctors and patients are malpractice and negligence. Between malpractice and negligence there are differences as follows: $:^{20}$

1. Malpractice that is done intentionally (a term of malpractice in the narrow sense) or can be referred to criminal malpractice, which is doctor actions clearly violate the law, including:

a. Having an abortion

b. Euthanasia

c. Giving false certificates or their contents is not in accordance with the actual situation, etc.

2. Negligence is a form of deed committed without being learned, such as:

a. Due to the medical record being exchanged, the doctor mistakenly performed surgery on the patient

b. The doctor forgets to provide information to patient who will undergo surgery, so the operation is done without informed consent.

Guwandi also stated the difference between malpractice and negligence can be seen from the motives and goals of the action, namely: ${ }^{21}$

1. Malpractice (in the narrow sense), is an action carried out consciously, with a purpose to the predictable effect or the doctor does not care about the consequences of the actions that he knows violates the law

2. Negligence, the doctor does not expect the consequences of his actions. Those consequences occur outside the doctor will and there is no motive to cause these effects

Furthermore, Guwandi explained that medical accidents are different from malpractice or negligence. The characteristics of medical accidents are: ${ }^{22}$

1. An accident is an unexpected event, an accidental action (accident, misfortune, bad fortune, mischance, ill luck)

2. No element of fault (schuld) was found in the accident

3. Doctors have done their work in accordance with the medical profession standard and professional ethics.

\footnotetext{
${ }^{20}$ Isfandyarie A.: Tanggung Jawab Hukum dan Sanksi bagi Dokter Buku 1. Prestasi Pustaka Publisher, Jakarta (2006).

${ }^{21}$ Guwandi, J.: Hukum Medik (Medical Law). Balai Penerbit FKUI, Jakarta (2010).

${ }^{22}$ Guwandi, J.: Hukum Medik (Medical Law). Balai Penerbit FKUI, Jakarta (2010).
} 
4. Accidents contain elements which cannot be blamed (venwijtbaarheid), cannot be prevented (vermijdbaarheid) and the events cannot be predicted

5. Doctors have taken fully caution action, make efforts seriously by using all their knowledge, skills and experiences

6. Doctor has tried to minimize the possible risks by conducting a thorough anamnesis, adequate preliminary examination, and necessary investigation

7. In the case of surgery/anesthesia, the doctor has tried to do initial therapy for the abnormality found or has consulted with other specialist doctors who are competent with the patient disorder.

In case of health care workers suspected of negligence in carrying out their profession, that's negligence must be resolved first through mediation. ${ }^{23}$ Before reaching the level of dispute, usually preceded by a gap between the patient's expected and a fact, then causes a sentiment problem, both interpreted internally (inner conflict) or externally to be disclosed out in the form of complaint; this is called conflict. ${ }^{24,25}$

Doctor legal responsibility in civil law has two main forms of responsibility, namely:

1. Liability for losses caused by default

2. Liability for losses caused by unlawful acts

Basically, civil liability aims to obtain compensation for losses. ${ }^{26}$ Therefore, the basis for claiming doctor responsibility is regarding unlawful acts or defaults; it is given the right to the injured person to receive compensation as an obligation from the other parties.

Claims for default are usually in the form of compensation claims against doctors who are considered to have committed an adverse act. Patient must have evidences of loss as a result of the doctor's unfulfilled obligations to him.

In a lawsuit against a doctor for unlawful conduct (onrechtmatige daad), patient must show the doctor's error which, due to his negligence in carrying out his professional obligations, causes harm to the patient. The occurring losses must be explained as a result of the doctor's negligent actions, or in the other words there is a clear causal relationship and no justification reason. ${ }^{27,28}$

A doctor can be declared wrong and pay compensation if between the losses incurred there is a close relationship with the doctor mistakes. In determining the doctor mistakes, we must refer to the professional standards. ${ }^{29}$ So that in the implementation of medical practice, acts against the law

${ }^{23}$ Junaidi, E.: Mediasi dalam Penyelesaian Sengketa Medik. Penerbit Rajagrafindo Persada, Jakarta (2011).

${ }^{24}$ Bahar, A.: Menjadi Pasien Cerdas: Terhindar dari Malpraktik. PT Kawan Pustaka, Jakarta (2005).

${ }^{25}$ Ratman, D.: Mediasi Non Litigasi terhadap Sengketa Medik dengan Konsep Win-Win Solution. Penerbit PT Elex Media Komputindo, Jakarta (2012).

${ }^{26}$ Ta'adi, Hukum Kesehatan: Sanksi dan Motivasi bagi Perawat. Penerbit Buku Kedokteran EGC, Jakarta (2013).

${ }^{27}$ Hariyani, S.: Sengketa Medik: Alternatif Penyelesaian Perselisihan antara Dokter dengan Pasien. Penerbit Diadit Media, Jakarta (2005).

${ }^{28}$ Isfandyarie A.: Tanggung Jawab Hukum dan Sanksi bagi Dokter Buku 1. Prestasi Pustaka Publisher, Jakarta (2006).

${ }^{29}$ Iskandarsyah, M.: Tuntutan Pidana dan Perdata Malpraktik. Permata Aksara, Jakarta (2011). 
can be identified with the doctor contrary actions or not in accordance with the medical professional standard.

Types of threats of punishment that can be imposed on doctor include:

1. Administrative punishment by the authorized health official based on Act Number 29 of 2004 concerning Medical Practices, Regulation of the Minister of Health Number 1419 / Minister of Health / Regulation / X / 2005 concerning the Implementation of Doctor and Dentist Practices, and Indonesian Medical Council Regulation Number 1 of 2005 concerning Doctor and Dentist Registration.

2. Penalty compensation for patients based on The Civil Code (KUH Perdata) and Act Number 8 of 1999 concerning Consumer Protection.

3. Criminal penalties based on Act Number 36 of 2009 concerning Health, The Criminal Code (KUHP), and Act Number 29 of 2004 concerning Medical Practices.

\section{Conclusion}

In the legal responsibility of a doctor as the bearer of the profession, the doctor must always be responsible for carrying out his profession. Because the responsibilities of doctors in law are so broad, doctors must also understand the legal provisions that apply in the implementation of their profession, including the rights and obligations of doctors and patients.

\section{References}

[1] Bahar, A.: Menjadi Pasien Cerdas: Terhindar dari Malpraktik. PT Kawan Pustaka, Jakarta (2005)

[2] Guwandi, J.: Dokter, Pasien, dan Hukum. Balai Penerbit FKUI, Jakarta (1996)

[3] Guwandi, J.: Informed Consent. Balai Penerbit FKUI, Jakarta (2004)

[4] Guwandi, J.: Hukum Medik (Medical Law). Balai Penerbit FKUI, Jakarta (2010)

[5] Hanafiah, J. \& Amir, A.: Etika Kedokteran dan Hukum Kesehatan. Penerbit Buku Kedokteran EGC, Jakarta (2012)

[6] Hariyani, S.: Sengketa Medik: Alternatif Penyelesaian Perselisihan antara Dokter dengan Pasien. Penerbit Diadit Media, Jakarta (2005)

[7] Ide, A.: Etika dan Hukum dalam Pelayanan Kesehatan. Gracia Publicer, Yogyakarta (2012)

[8] Isfandyarie A.: Tanggung Jawab Hukum dan Sanksi bagi Dokter Buku 1. Prestasi Pustaka Publisher, Jakarta (2006)

[9] Iskandarsyah, M.: Tuntutan Pidana dan Perdata Malpraktik. Permata Aksara, Jakarta (2011)

[10] Junaidi, E.: Mediasi dalam Penyelesaian Sengketa Medik. Penerbit Rajagrafindo Persada, Jakarta (2011)

[11] Komalawati, D.V.: Peranan Informed Consent dalam Transaksi Terapeutik: Persetujuan dalam Hubungan Dokter dan Pasien, Suatu Tinjauan Yuridis. Penerbit Citra Aditya Bakti, Bandung (2002) 
[12] Kusumastuti, E.: Transaksi Terepeutik dalam Upaya Pelayanan Medis di Rumah Sakit. PT Citra Aditya Bakti, Bandung (2009)

[13] Machmud, S.: Penegakan Hukum dan Perlindungan Hukum bagi Dokter yang Diduga Melakukan Malpraktik. Penerbit Mandar Maju, Bandung (2008)

[14] Marzuki, P.M.: Penelitian Hukum. Penerbit Kencana, Jakarta (2010)

[15] Munir, F.: Sumpah Hipocrates: Aspek Hukum Malpraktek Dokter. PT Citra Aditya Bakti, Bandung (2005)

[16] Ngani, N.: Metodologi Penelitian dan Penulisan Hukum. Penerbit Buku Yustisia, Yogyakarta (2012)

[17] Notoadmodjo, S.: Etika dan Hukum Kesehatan. Penerbit Rineka Cipta, Jakarta (2010)

[18] Ratman, D.: Mediasi Non Litigasi terhadap Sengketa Medik dengan Konsep Win-Win Solution. Penerbit PT Elex Media Komputindo, Jakarta (2012)

[19] Suherman, A.M.: Aspek Hukum Dalam Ekonomi Global. Ghalia Indonesia, Jakarta (2002)

[20] Supriadi, W.C.: Hukum Kedokteran. Penerbit CV Mandar Maju, Bandung (2001)

[21] Ta'adi, Hukum Kesehatan: Sanksi dan Motivasi bagi Perawat. Penerbit Buku Kedokteran EGC, Jakarta (2013)

[22] Tengker, F.: Hak Pasien. Penerbit CV Mandar Maju, Bandung (2007) 